"The EUrASEANs: journal on global socio-economic dynamics"

Volume 2 (21); March-April, Year 2020;

ISSN $2539-5645$ (Print)

Copyright (C) 2019, [The EUrASEANs]

on-line access: https://www.euraseans.com/2(21)

\title{
THE US-CHINA TRADE WAR AND ITS IMPACT ON THAILAND'S ECONOMY
}

\author{
IrinaV. Onyusheva \\ Turan University, Almaty, Kazakhstan \\ Rungnapa Khamboocha \\ Nipaporn Muangmutcha
}

Stamford International University, Bangkok, Thailand

This paper analyzes the economic consequences of the trade war ongoing between the USA and China as applied to Thailand. The paper mainly focuses on the relationship between the global tariffs' imposition during this US-China trade war as they directly hit several Thai export products as well as the US-China trade war impact on Thai business via dumping goods into Thailand and Thai products intermediately affected by the tariffs imposed on Chinese or US goods. Recently, it has been illustrated by many researchers and economists that trade wars, especially between those waged between such large economies have adverse economic effects on the global economy and international trade. This paper utilizes PESTEL and also causes and consequences analysis to explain the trends of the US or China exports of goods and services to Thailand, Thai intermediate inputs indirectly affected by the tariffs imposed on Chinese or US goods and dumping goods into Thailand as the latter could intensify domestic competition.

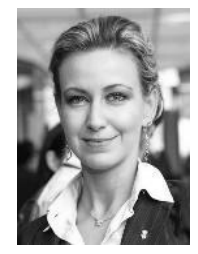

\section{Irina V. Onyusheva}

Dr., Prof., Turan University, Almaty, Kazakhstan.

Research interests: strategic management, increasing economic competitiveness at both micro- and macro- levels; human capital development; HR management; knowledge economy; knowledge management; project management; management in education.

E-mail: dr.irina.onyusheva@gmail.com

\section{Rungnapa Khamboocha}

Stamford International University, Bangkok, Thailand; International MBA Program Research interests: international business management, strategic management, HR management.

E-mail: rungnapa.k@gmail.com

\section{Nipaporn Muangmutcha}

Stamford International University, Bangkok, Thailand; International MBA Program Research interests: international business management, strategic management, HR management.

E-mail: nip.m@gmail.com 


\section{THE US-CHINA TRADE WAR AND ITS IMPACT}

Keywords: international business; world economy; trade impacts; USA; China; Thailand; trade war; tariffs

\section{Introduction}

International trade is the exchange of goods and services across national borders. In most countries, it represents a significant part of gross domestic product (GDP). This type of trade increases the number of goods that domestic consumers can choose from, decreases the cost of those goods through increased competition, and allows domestic industries ship their products abroad. International trade has become the engine of growth for most of economies for many centuries. However, some problems exist in it, such as trade barriers and tariffs, and they have demonstrated to cause more economic harm than benefits.

Trade barriers raise prices and reduce the availability of goods and services, thus resulting, in the long term, in lower income, reduced employment, and lower economic output (York, 2018). Since the end of the World War II, the world has largely moved away from protectionist trade policies toward a rules-based, open trading system. This widespread reduction in trade barriers has contributed to economic prosperity in many ways, including large increases in trade activity and accompanying gains in economic output and income (York, 2018).

The most famous form of trade barriers is maintaining protectionism through imposing import tariffs. Continuous imposition of retaliatory tariffs results often means the start of a trade war. A trade war is when countries try to attack each other's trade with additional taxes and quotas. One country raises tariffs or taxes, thus causing the other side to respond, in some sort of a tit-for-tat escalation. This can intermediary hurt other nations' economies and may lead to rising political tensions between them. Trade wars have been proved to have no winners and have negative economic and political consequences on the countries engaging in them, and the global economy overall.

On March 22, 2018, Donald Trump, the acting president of the United States signed the memorandum under Section 301 of the Trade Act of 1974, instructing the United States Trade Representative (USTR) to apply tariffs of $\$ 50$ bln on Chinese goods. Trump stated that the tariffs would be imposed due to Chinese theft of the US intellectual property which costs the US economy a lot (Brown \& Kolb, 2018). In fact, Donald Trump started the war, raising import tariffs on solar panels in January 2018, while their main supplier is China. In response, on April 2nd, China raised import duties on 128 commodities originating from the United States. China and USA are Thailand's largest trading partners, and as Thai economy is export driven, there will be both direct and indirect impacts for different sectors of Thai economy.

Thus, this paper explains consequences of the US-China trade war for Thai economy through discussing previous literature on the origins of the trade war, China's response to trade war and the impact of US-China trade war for Thai economy by using PESTEL and causes \& consequences analysis. Eventually, this paper provides the summary on the case and the main findings of the study. 


\section{Literature Review}

There are three key principles of international trade. First, many non-economists believe that it is more advantageous to trade with other members of one's nation or ethnic group than with outsiders. Economists see all forms of trade as equally advantageous. Second, many non-economists believe that exports are better than imports for the economy. Economists believe that all trade is good for the economy.

Third, many non-economists believe that a country's balance of trade is governed by the "competitiveness" of its wage rates, tariffs, and other factors. Economists believe that the balance of trade is governed by many factors, including the above, but also including differences in national savings and investments (Kling, n.d.).

Since 1947, when the General Agreement on Tariffs and Trade (GATT) was created, the world trading system has benefited from eight rounds of multilateral trade liberalization, as well as from unilateral and regional liberalization. Indeed, the last of these eight rounds (the so-called "Uruguay Round" completed in 1994) led to the establishment of the World Trade Organization to help administer the growing body of multilateral trade agreements (IMF, 2001).

Free trade, also called laissez-faire, a policy by which a government does not discriminate against imports or interfere with exports by applying tariffs (to imports) or subsidies (to exports). A free-trade policy does not necessarily imply, however, that a country abandons all control and taxation of imports and exports (Dixon, n.d.).

Free trade can be done unilaterally by a country or bilaterally by entering regional trade agreements with other countries like NAFTA and TPP. The theoretical basis for free trade stems from the arguments of Adam Smith and David Ricardo. Free trade enhances competitiveness and innovation through technology transfer across countries. Free trade increases access to higher-quality, lower-priced goods, reduces imported-input costs, thus reducing business production costs.

In addition, free trade also encourages labor specialization and labor division so that labor resources acquire more skills. This, in turn, leads to accumulation of human capital which eventually increases economic growth. Moreover, it simulates job opportunities by increasing employment. For example, by 2011, productivity in the United States had risen to about $170 \%$ of what it was when the North American Free Trade Agreement was instituted (Shaiken, 2015).

Trade openness in the sense of 'neutrality' or neutral trade orientation of an economy may have positive impact on economic growth in the short run through increased technology transfer, transfer of skills, increased labor and total factor productivity and economic growth and development. International trade has positively influenced economic growth as it injects global competitiveness and hence domestic business units tend to become very efficient being exposed to international competition.

Developing countries have higher trade protectionism measures as compared to developed ones. Products that are labor-intensive are exported by developing countries to both developed and underdeveloped countries, thus bringing it reduction in the poverty level and not only.

However, the United States has been experiencing trade deficits for the past several years. The US-China trade dispute stems from the persistent growth in the US trade deficit with China as well as the increasingly intensifying technological competition between these 


\section{THE US-CHINA TRADE WAR AND ITS IMPACT}

two huge nations. Since the US has been persistently experiencing trade deficit, there are predictable negative consequences that can affect its economic growth and stability, particularly imports are more in demand than exports; domestic jobs may be lost to those abroad. Therefore, many countries adopted a trade protectionist policy imposing tariffs and restricting imports of foreign goods and services in order to protect their own industries and companies manufacturing similar items. Indirectly, this also helps with raising additional tax revenues. A serious problem with trade protectionism is that nations will take reciprocal action if there are trade protection policies put into effect.

The problem here is that nations will retaliate if they cannot sell their goods and products at the markets where they normally could. No matter if those nations are political and military allies, nations will impose countervailing tariffs, quotas, subsidies, and exchange rate controls, to name a few, in order to deal with another nation's actions (Guarino, 2018). An international trade war hinders economic growth, increases goods prices and promotes inflation. It costs jobs, causes inefficiency and reduces the volume of international trade. It disrupts global supply chains and creates trade diversion which is inefficient.

China and US are Thailand's largest trading partners, and as Thai economy is exportdriven, there will be direct and indirect impacts to its different sectors. The most immediate direct effect which can arise in times of loggerheads is for the mutual tariff imposition to cause products of both trade giants to be dumped into Thailand, thus resulting in stiffer competition with Thai domestic products. However, imposition of tariffs between the US and China may lead to an increasing demand for Thai products that are substitutable at these two markets.

Thus, our research questions are:

1) How does global tariff imposition from the US-China trade war impact on various Thai export product categories?

2) How is Thai business impacted in the course of the US-China Trade War?

3) How is the supply chain (Thai intermediate products) affected by the tariffs imposed on Chinese and US goods?

\section{Key Research Results}

\section{PESTEL}

Here we are using the PESTEL method as we are analyzing causes and effects that will occur in Thailand from the trade war between the United States and China.

The reason for the trade reaction between the United States and China at this time is the US effort to pressure China to adjust its trade policies to the same standards as other major industrialized countries. China is expected to end subsidies for domestic industries, stop intellectual property infringement and allow more openness for foreign investments. The United States uses pressure on China in many ways. Below we outline the major ones.

Political factors. This war is not just a trade issue, but a global political problem which indirectly also influences Thai politics. If this trade war would soon have more severe impacts, it could actually become a new round of the "Cold War". At the same time, politics in Thailand is another big issue that was putting pressure on the growth of the Thai economy 
in 2019. Thai government has a team of professional economists to analyze and consult on various situations during this uneasy period.

Since the decrease of Thai exports, it is expected that private consumption and investments will slow down. This may have great impact on the economy because of the problems with Thai politics and elections, both being no good news currently. Today both Thai and foreign investors are still waiting to invest while economic climate in the country is still rather sluggish. On the other hand, if the United States does not import Chinese products, it must be importing from other countries, and this may be beneficial for Thai economy. At the same time, this also means that Thai entrepreneurs will be struggling in competition with Vietnam, Malaysia and some other Asian countries.

This trade war is like a "new phenomenon" in trade of the 21 st century, or a "disruptive global market" that makes world trade change like technology, while smartphones are making businesses changes even more radical. The United States has tried to create uncertainty and pull the global supply chain from China as such. In this situation, turning to other Asia countries or ASEAN in particular, Thailand will definitely benefit. Therefore, if new, incoming governments are knowledgeable about the most recent trends in international trade, thyy should pull investment into Thailand. At the same time, taking into account the Eastern Economic Corridor Zone (EEC) as the major destination point, Thailand must increase its competitiveness as a country, creating confidence, among traders and investors, so that they see that "Thailand is the final destination".

Partial relocation of China's production facilities to 3rd countries might have a good impact on Thailand. But Thailand has to make itself ready and become more interesting for investors. More importantly, investors should see that Thailand is stable and suitable for their investments. The government should accelerate the implementation of various mega projects in order to attract investment. Some of them are Thai opportunities but must act properly for this opportunity. And Thai government may consider adopting more of economic support measures in order to discourage exports and hinder the economic slowing down which affects employment rate, household spending and the state of business sector overall.

In this regard, the government has already introduced the policy "Thailand 4.0" (Thailand Business News, 2016) as a policy vision that transformed the traditional economy into an economy driven by innovation so that all citizens can adapt and develop in the direction to stability, wealth and sustainability. The key guidelines of this policy include:

-Industrial sector: To drive technology creativity and innovations;

- Agriculture: It must be changed from traditional agriculture to more modern agriculture that focuses on new methods of management and the use of most advanced technologies as such "smart farming";

-Switching from traditional SMEs to smart enterprises and startups with higher development potential;

-Switching from the traditional service model with relatively low value creation to high-value services;

- Switching from low-skill workers to highly knowledgeable and skilled workers.

Thai government expects that talented Thai people will intend to innovate and produce highly valuable innovations. The government has been already trying to support these people in all aspects like training, funding, encouragement and confidence. 


\section{THE US-CHINA TRADE WAR AND ITS IMPACT}

Economic factors. The global economy has the growth rate of $0.3 \%$ now, down from $3 \%$. Thai share of exports to China as of November 2018 was 8.9\%. At the same time, Thai manufacturing production index continued to expand, partly due to the fact that Thailand has diversified its export market quite well. The country today is not relying on one market too much. At present, Thailand also exports to the United States, China, Japan, the EU and CLMV in the same proportion of approximately $10 \%$ each. Therefore, economic slowdown does not affect Thai economy same as the countries mentioned above (Office of the National Economic and Social Development Council, 2019).

At present, Chinese economy has the average growth rate of 6\% (Tan, 2019). The related factors that may affect Thailand are: Chinese tourists will travel less abroad and will travel less to Thailand; same is applicable to the tourists from Europe, this important market share will also decrease. Thailand tried hard to increase tourism volume in the country back in 2019, 40.3 million people visited this country in 2019 along, however, its economic growth remains to be below $3.5 \%$ (Sritama, 2019)

The impacts of the global economy and of the trade war on Thai-Baht is also getting stronger. Thai exchange rate is relatively stable, especially if compared to country's key regional competitors. However, its fluctuations made Thai exports continue to decline in the period from the fourth quarter of 2018 to the first quarter of 2019. Therefore, it is expected that in 2019, Thai exports will expand in the range from $-1 \%$ to $1 \%$ from the previously expected rate of 2-3\% (Thaichareon, 2019; Trading Economics, 2019). The United States may also add Thailand to foreign exchange intervention countries. In this case, the government must have a very high level of negotiation skills. Otherwise Thailand may have other problems as well, not just with the currency exchange rate.

There are also predictions that China may relocate part of its manufacturing facilities to Southeast Asia and other regions. However, when attracting investments from China to Thailand or relocating production bases to Thailand, there are also important things to be aware of in the case of China continuing to have problems with the United States. If China sets up factories in Thailand, it will be using Thailand as a base for export to the United States. Eventually, Thailand may have problems with the United States, while Thailand certainly does not want to have any problems with both countries (Rapoza, 2019).

The impact on Thailand will be both positive and negative because Chinese exporters will still export products to the United States, but in a tricky way. At the same time, US export to China will also become more difficult. Thai products that are in the production chain of China will also become more difficult to export, and quite many products in this group will be affected. But other products, that are not in Chinese supply chain, such as agricultural food products, will become a good replacement for Chinese products at the US market, some of them may even replace US products in China (Limviphuwat, 2019A).

Therefore, there should not be too much of a panic, even though the stock prices are hit. If we look at the best case scenario, there is a possibility all these substitutions will go as high as up to 50\%, but this also means more concern about the related risks. Many investors may find it necessary to invest mostly in the assets that are safe and low-risk, such as deposits or government bonds.

Social factors. Society, culture, living style, habits of people in Thailand are not affected that much by the trade war between the United States and China. Moreover, even 
life/work values and consumer spending behavior are not affected by this trade war, at least for now.

Socially it won't affect Thailand directly but it could pose a problem for Thai Chinese or even American-Chinese business owners which have connections with the mainland of China. If they have a factory located there, this means they would be forced to cease trade with the United States. The largest problem for regular Chinese or Americans who are living in different parts of the world and who are participating directly in this trade war is that if they bring or buy a certain product which is American or Chinese, they have to go through customs and they must make a decision whether they want to pay this ridiculous tax or let customs confiscate the item. Another alarming issue, for streetwear enthusiasts especially is that quite many famous brands originate from the US, for example, Bape, Champions, Supreme and more, and since they are already quite expensive, this trade war will make the prices skyrocket even higher.

Technological factors. President Donald Trump on 15 May 2019 (BBC News, 2019) announced that the government does not allow US companies to use telecommunications equipment that is based on technology vulnerable in terms of national security, including primarily those by Huawei in China. Reasoning that it may affect the stability of the country, the United States tried to use trade measures to prevent the entry of 5G technology, which China achieved before the United States. During the recent decades, China has developed very fast economically and technologically, so the US would like to see this development hindered. This concerns first and foremost trade and technology.

Therefore, this mutual resistance is causing trade tensions which will not end easily. Such events convince the United States allies to stop using equipment or technology of Chinese telecommunications companies as well. This is resulting in a decrease in Chinese exports, especially various IT products and electronic circuit boards which are the main products of this category in China. This also resulted in Thai exports' decrease in 2018 until 2019 as Thailand is a major exporter of China, and this is, inter alia, applicable to IT products, electronics and electrical circuit boards. This has a serious impact for Thai exports because Thailand has a few export products that make huge income in the country (Kasikorn Research, 2018).

Such tensions between China and the United States will, most probably, continue in the long run. This trade war will affect the supply chain of various industries around the world, and Thai technology industry is no exception in this regard (SCB EIC, 2018). This situation is already forcing many companies in Thailand to change their supply chain policies so that to prepare themselves for the ongoing trade war. This especially concerns the information technology companies, textile companies, furniture and agricultural producers.

The US 20-25\% increase in finished goods tax on the commodities from China is considered to have a major impact on Thai exports because Thailand normally exports raw materials to China (Chaitrong, 2018), including agricultural crops, electrical appliances parts, auto parts, electronic circuit boards, plastic pellets, rubber, and in total - more than 5,700 items. When China cannot export its finished products to the United States, this also becomes a real crisis for Thailand. This also means China will turn to export to the ASEAN instead of the US market. And Thailand is the main target country for China to deliver its products. If so many products come into Thailand, this may result in many Thai entrepreneurs having to close their businesses as such. 


\section{THE US-CHINA TRADE WAR AND ITS IMPACT}

Under this crisis, there are also opportunities because Chinese entrepreneurs may move their production facilities in many industries into Thailand. For Chinese manufacturers this might be one of the easiest ways to escape the trade war. But this means some risks in the long run, in terms of employment of Thai people and also trade surplus. Currently, Thailand is number 12 on the US trade balance list, and if China actually moves its production facilities to thic country (Money2know, 2019), the United States may raise tariffs on imports from Thailand as well.

Environmental factors. Taxes' increase raises concerns that trade wars may affect the global trade climate and the world economy. Also, they affect the purchasing power of both Chinese and American consumers. Indirectly, higher taxes are causing Thailand dropping exports as well. Chinese government media warned the United States that China may not export rare or "rare Earth" (an important raw material for smartphones' production and electric cars) to the United States. There was also a warning delivered by Chinese official media that China will use rare minerals as a weapon in this trade war with the United States as a weight issue (The Guardian, 2019). Chinese authorities has already used media as their communication channel to announce important diplomatic gestures in the past.

Although this trade war will affect Thailand in a mostly negative way, there are still products that will receive benefits from it, especially agricultural products and furniture. However, it is important that Thailand must maintain product quality in order to maintain competitiveness. The key product groups that have the opportunity to benefit from these trade barrier measures include (NESDB, 2019):

(1) Product groups with the opportunities at both US and China markets, such as plants;

(2) Product groups that have opportunities in a particular market, such as textiles and clothing, chemical industry, leather products;

(3) Groups affected by trade wars, including plastics, rubber, fat and vegetable oil products derived from animals or plants etc.

In what concerns environmental issues, the following Thai industries are affected most of all:

Petrochemical industry: At present, this industry has sufficient capacity utilization, but its capacity expansion may occur in the future;

Textile and apparel industry: Currently, part of it has been relocated from China to other countries in the ASEAN region, with high-end products being relocated mostly to Thailand. Since there are forecasts that this industrial production sector will grow sustainably, it is necessary to develop more innovative products in it;

The steel industry: It is expected to be growing in the current year in line with the economic conditions in neighboring countries.

Furniture industry: It is expected to expand thanks to supporting factors, like extra investments in condominium construction and other real estate construction projects. In addition, Thai furniture industry still has solid strengths in terms of modern design as compared to closests competitors from other countries.

The plastics industry: Expected to continue growing;

Environmental sector: The popular trend of trying to reduce carbon emissions will requires the use of low sulfur diesel oil. And this, in turn, will result in higher production costs for operators. 
At present, business and other organizations in Thailand are trying to drive important Thai exports. This is done mostly through defining and planning new marketing strategies for penetrating the Indian market and also closer ASEAN markets. Promoting online commerce is another trend which can be vitally supporting for Thai entrepreneurs who would like to expand their exports to Chinese and Indian markets through online channels (Arunmas, 2018). Finally, the use of big data and similar online services might help integrate all services and operational data and thus support Thai businesses.

The US-China trade war is expected to become even more intense, although not directly affecting Thailand because more products will be imported to replace the missing ones at the market, especially agricultural products. However, future exports in Thailand will be most probably reduced in volume. Therefore, Thailand must produce commodities of higher than usual quality. Finding new partners or markets to support own development is also a good idea. Today Thailand is the Chair of the ASEAN, thus, the country can use this status to push for greater trade under the RCEP Strategic Partnership Agreement (MFA, 2019; Limviphuwat, 2019B).

Legal factors. Trade war between the United States and China so far has no impact on Thai legal environment. Although the United States uses tax barriers to counter the unfair trade of China, similarly unfair trade agreements are also initiated by some other countries.

Enforcement of the suggested tariffs wall make the products that the US imports from China almost half the import duty. It is also the largest tax barrier that the US has ever used. Moreover, this war can be already considered the biggest trade war in the history of the world economy! Collecting import duty on consumer goods is expected to cover the list of more than 6,000 items. This means that almost all Chinese products exported to the US will be subject to import duties such as handbags, rice, textiles, toilet paper, wool, luggage and furniture. This is already causing more concerns related to the US trade deficit.

US companies are also concerned about the rising costs of doing business. They are also warning that the employment rate may go down. This is already happening at many US companies, including Apple and Dell. American businesses are fearing that this tariff will increase their costs because many of their products are manufactured in China. In parallel to that, consumers and households are beginning to recognize the impact of already rising prices.

On Chinese side, the government has expressed dissatisfaction with this movement. China raised taxes on the products imported from the United States, in the total amount of 60 billion dollars (from 10\% to 25\%), effective as of 1 June 2019. And it may use other measures as well (Wong \& Koty, 2019). The US agricultural products will be most affected by this tax increase, as this increase concerns such product categories as beans, sugar, wheat, chicken and turkey (Snyder, 2019). Interestingly, this Chinese response is aiming primarily at the products that belong to farmers, the typical voters of the president Trump.

Trade deficit is generally seen as a result of savings and investment rather than trade policies. Countries that spend more than they earn will also lack trade balance. This and other policies of the President Trump, including tax cuts, would allow the government borrow more money, which automatically means reducing the country's savings and growing trade deficit more.

At present, Thailand is directly affected by these changes in tariffs in everything what concerns trade and in some other aspects. But Thai legal system and environment have not 


\section{THE US-CHINA TRADE WAR AND ITS IMPACT}

been directly affected. However, if in the future, this trade war damages Thai economy severely, Thai legal regulations or policies may be changed accordingly, so that to protect Thai economy and not allow other countries get benefits instead of Thailand.

\section{Economic Consequences}

Thailand is an export-driven country which relies heavily on trade partnerships with other countries to keep its economy alive and well. Thailand's exported goods plus services represent $68.2 \%$ of the total Thai economic output or Gross Domestic Product. Exports this year are expected to see high growth with a record high in export value following the continued recovery in global trade and economy, despite the risks from trade barriers and exchange rate volatility.

The following products are the 10 most in-demand goods shipped from Thailand during 2018 (Workman, 2019):

1. Computers, optical readers, value -- 12.7 billion USD;

2. Cars, value --11.1 billion USD;

3. Automobile parts/accessories, value -- 8.5 billion USD;

4. Integrated circuits/microassemblies, value -8.3 billion USD;

5. Processed petroleum oils, value -- 8.2 billion USD;

6. Trucks, value -- 7.8 billion USD;

7. Rice, value -- 5.6 billion USD;

8. Air conditioners, value -5.3 billion USD;

9. Rubber tires (new), value -- 4.9 billion USD;

10. Natural rubber, value -- 4.6 billion USD.

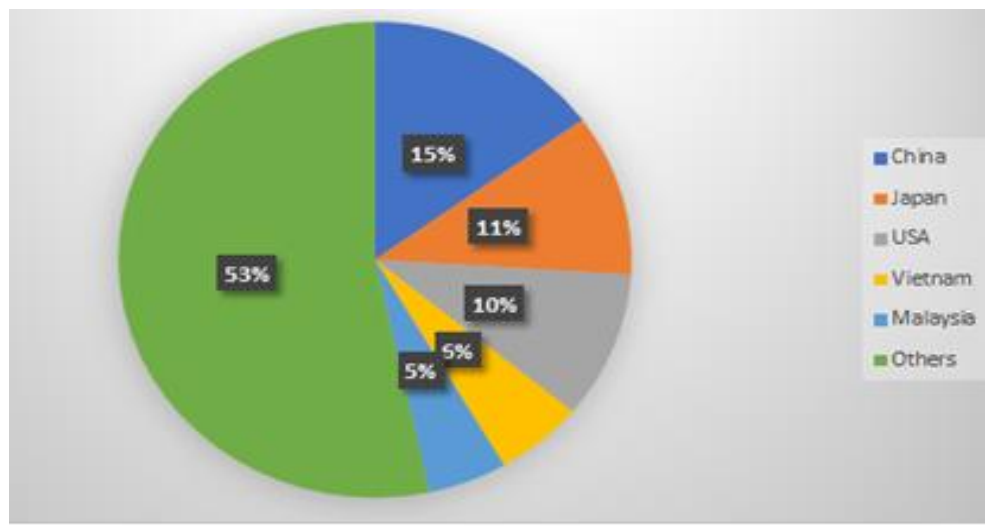

Figure 1 - Thailand exports by country, according to the United Nations (Source: COMTRADE database on international trade, 2017)

Referring to Figure 1, China and the United State of America are Thailand's largest trading partners. Back in 2017, Thailand's exports to the USA covered 10 percent with the value of 17.80 bln USD, and exports to China contracted 15 percent with the value of 26.38 bln USD respectively. After that, Thai exports dropped unexpectedly by $5.2 \%$ as the USChina trade war escalated.

The value of Thai exports in September 2018 sank by $-5.2 \%$ YOY, the first drop in 19 months. This rather unexpected decrease, due to export drops in multiple product groups, was 
led by a group of industrial products which altogether fell by $-6.7 \%$ YOY. This group includes: automobiles, their accessories and parts (-7.4\% YOY), electronic machines (-4.1\% YOY), electrical appliances (-0.8\% YOY), and especially gold which dropped significantly at $-78.7 \%$ YOY from $-66.6 \%$ YOY in the previous month. Excluding gold, the growth of Thai exports in September was at $-0.8 \%$ YOY.

Agroindustrial products also fell by $-1.6 \%$ YOY, including processed and canned seafood, processed shrimp, white refined sugar, and processed and canned fruits. However, agricultural product exports grew slightly, at $0.1 \%$ YOY, following the growth mainly in rice and cassava. Meanwhile, the exports of rubber and sugar continued declining due to falling prices. During the first 9 months of 2018, the growth of Thai exports was at $8.1 \%$ YOY (Photirat, 2018).

The US-China trade dispute stems from the persistent growth in the US trade deficit with China as well as the increasingly intensifying technological competition between the two nations. In addition to that, the first two rounds of the global tariffs imposed by the US on solar panels and washing machines (under Safeguard section 201) and on steel and aluminum (under National Security section 232) became effective in March 2018, thus continuing the influence on Thai exports.

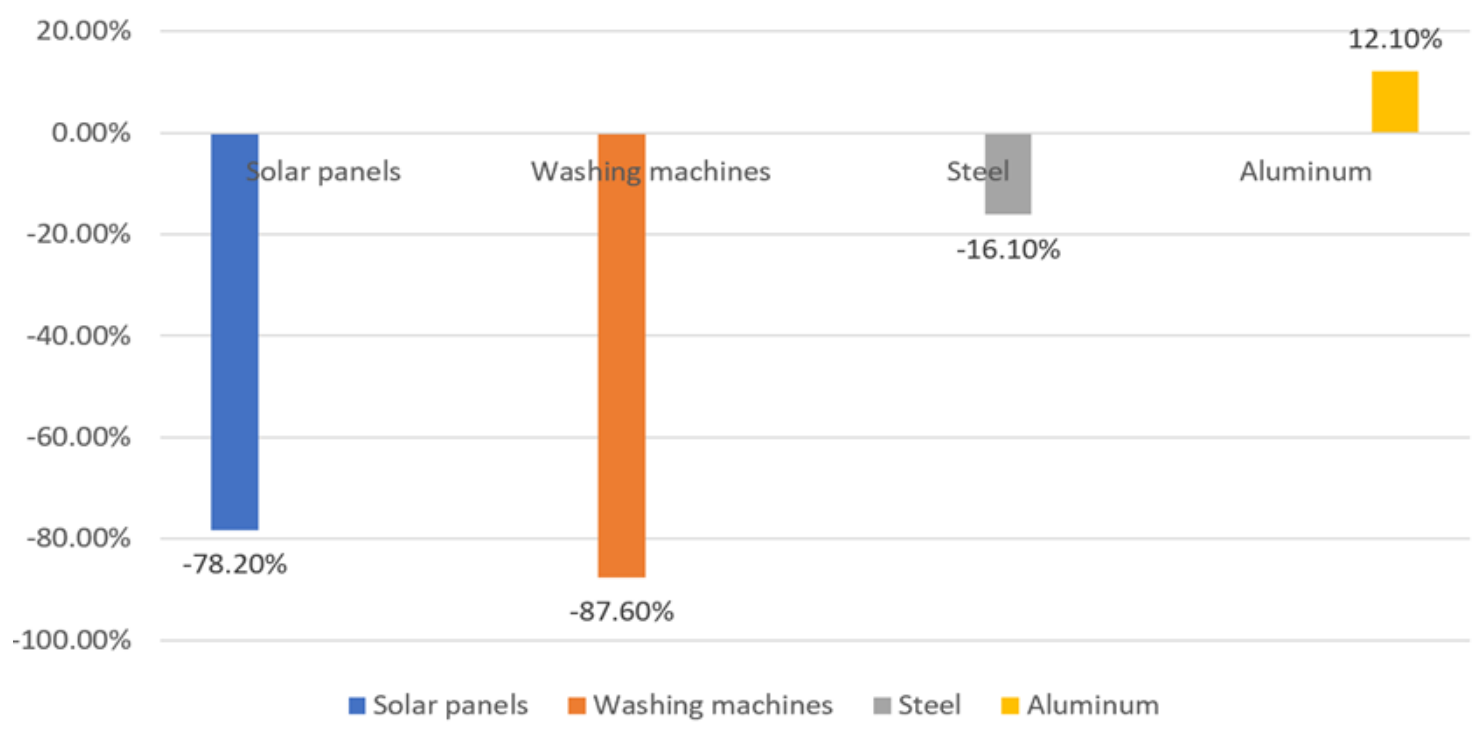

Figure 2 - Thailand exports of goods to the United State of America, 2018 (Source: SCB EIC, 2018)

We can see that the values of Thai exports affected by the US import tariffs including solar panels and washing machines, dryers and parts, dropped by $-78.2 \%$ YOY and $-87.6 \%$ YOY respectively. These falls resulted in a significant drop in Thai exports in these product groups to all markets, by $-38.3 \%$ YOY and $-44.6 \%$ YOY respectively.

Meanwhile, Thai exports of iron, steel and steel products to the US returned to be negative at $-16.1 \%$ YOY after growing by $12.6 \%$ YOY in August. At the same time, the exports of iron, steel and steel products to other markets accelerated from $2.4 \%$ YOY to $4.4 \%$ YOY. In the meantime, exports of aluminum products continued improving in general and to the US in particular, at 12.1\% YOY and 38.2\% YOY respectively (Photirat, 2018). 


\section{THE US-CHINA TRADE WAR AND ITS IMPACT}

On the other hand, the US-China trade war generated greater impacts on Thai exports to China as follows.

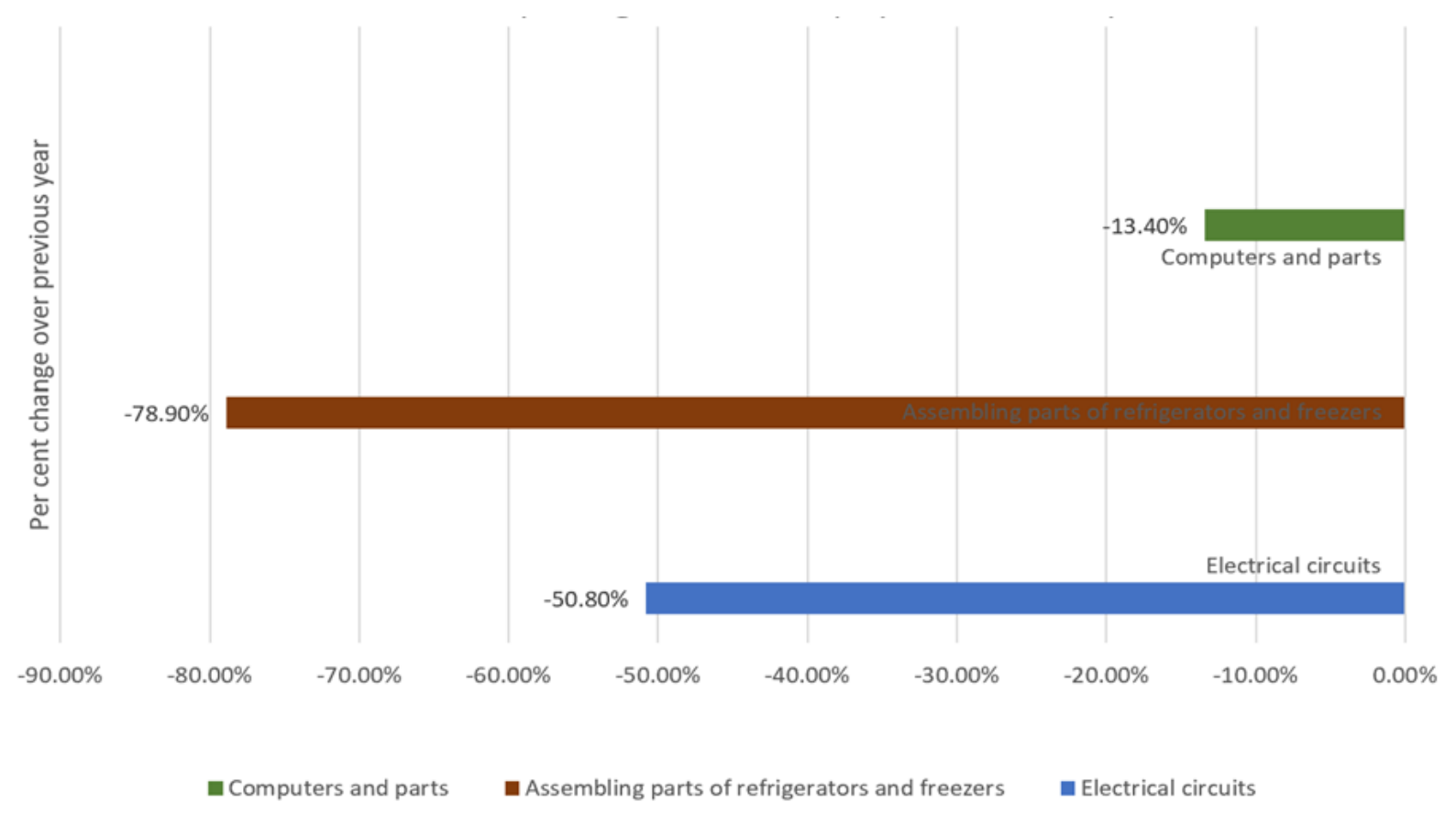

Figure 3 - Thailand exports of goods to China, growth during 2018

(Source: SCB EIC, 2018)

In Figure 3 we can see that Thai exports to China in September 2018 declined significantly, at $-14.1 \%$ YOY. This was expected, partially due to the US import tariffs on Chinese products activated on July 6 and August 23 of the same year. The affected trade value was USD 50 bln in total, which was the reflection of the notably dropped value of Thai exports anticipated to be related to the tariffs on Chinese exports to the US, namely, electrical circuits, and assembling parts of refrigerators and freezers. Thai exports of these products to China fell by $-50.8 \%$ YOY and $-78.9 \%$ YOY respectively. Meanwhile, Thai exports of computers and parts to China continued decreasing at $-13.4 \%$ YOY. Apart from that, the fall of Thai exports to China may as well be affected by China's economic slowdown (Photirat, 2018).

In this study we have found that the global tariff imposition during US-China trade war directly hits several Thai export categories, i.e., solar panels, washing machines, steel and aluminum (see Figure 2).

The supply chain (Thai intermediate products) was also affected by the tariffs imposed on Chinese or US goods, i.e., IT product, electronics and electrical circuits (see Figure 3).

\section{Discussion}

It is highly likely that the global tariff imposition during the US-China trade war directly hits several Thai export products. It also impacts Thai businesses in various sectors, and the supply chain (Thai intermediate products) is also affected by the tariffs imposed on Chinese or US goods. More specifically: 
1. The global tariff imposition in the course of the US-China trade war directly hits several Thai export products:

Thailand is one of the victims of the global tariffs D. Trump has imposed on solar panels, washing machines, steel and aluminum. As a result, the exports of solar panels and washing machines to the US dipped by $78 \%$ in September 2018.

Thai baht appreciation and Thai exchange rate is more stable than that of the closest competitors, causing Thai exports to decline.

Thai industrial production index continued to expand partly because Thailand has a relatively good distribution of the export market and the country does not rely on one market too much.

Since the United States does not import Chinese products these days, they must be imported from other countries, which may be beneficial for Thai economy. But Thai entrepreneurs must get prepared to fight with competitors from Vietnam, Malaysia and some other Asian countries.

It is a new United States policy to not use telecommunications that are based on technologies which can be vulnerable in terms of national security, this concerns Huawei in the first place. This is already resulting in a decrease in Chinese exports under such categories as IT products and electronic circuits, which are the main products of China. To a slight less extent this also concerns the trade partners of China, including Thailand and other ASEAN members. Thai exports under these categories are declining because Thailand is a major exporter of electronics and electrical circuits to China. This situation has a direct negative impact on Thai exports because Thailand has a small amount of export products that are generating huge revenues for the country.

20-25\% increase in finished goods tax from China is considered to have a major impact on Thai exports. Thailand exports to China normally include various raw materials, such as agricultural crops, electrical appliances parts, autoparts, electronic circuit boards, plastic resin, and rubber.

China will turn to export to the ASEAN instead of the US market and Thailand will be the main target in this Chinese products' delivery. China has lower production costs as compared to Thailand, therefore, inflow of Chinese exports may result in bankruptcy of many Thai entrepreneurs.

Entrepreneurs are also trying to look for opportunities from this trade war. Such opportunities may be found at specific markets such as textiles and clothing, chemical industry, leather products. Other groups that are directly affected by this trade war are: plastic, rubber, fat products, vegetable oils etc.

2. The impact on Thai businesses in this US-China trade war:

Inflow of cheap products from both US and China into Thailand could lead to higher competition for local players.

The government will accelerate various large-scale projects to attract investment and investors will see that Thailand is stable and suitable for investment.

Chinese entrepreneurs may move production bases in many industries into Thailand to use Thailand as a base to still export to the United States. This might become problematic for Thailand in a longer term since the United States may want to increase import tariffs for Thailand with the aim to "extract" Chinese production from this country. 


\section{THE US-CHINA TRADE WAR AND ITS IMPACT}

Investors are also concerned about the related risks. Therefore, they may change their mind and invest money only in low-risk assets, deposits or government bonds.

Investors, both Thai and foreign, are still waiting to invest more, even though the economic climate in this period seems to be rather sluggish.

3. The supply chain (Thai intermediate products) affected by the tariffs imposed on Chinese or the US goods:

Products especially affected by the tariffs imposed on Chinese or US goods include computer parts, electronics and optical parts, chemical products, motor vehicle parts and rubber.

Rubber industry is highly negatively affected as more than half of Thailand's rubber sheet exports go to China to be later manufactured into various products, ranging from car tyres to rubber gloves. This drop in demand from China due to the tariffs on its rubber products and auto parts caused prices to collapse by $20 \%$ since June 2018. Thai farmers are consequently suffering from this negative impact.

Electronics industry: Thai exporters and producers of upstream E\&E components such as integrated circuits (ICs), printed circuit boards (PCBs) and sensors may be affected if they belong in the US-China supply chain. For instance, ICs and sensors may be exported to China to be assembled in mobile phones, auto parts or automobiles before being exported to the US, and vice versa. Demand for these intermediate components may slow down due to mutual tariffs' imposition. Trade statistics has shown that Thai exports of ICs to China fell by $38 \%$ in October 2018. Moreover, Thai electronic companies with production based in China will likely be hit as well.

Automotive industry: Demand for auto parts and motor vehicles may decline due to tariffs on steel and aluminum, which are raw materials used to produce those products.

The United States tries to create uncertainty to pull the global supply chain from China. It may be seen that trade and investment have changed more and more in Asia and namely ASEAN. Thailand has good chances to capitalize on this situation.

Chinese exporters will experience more difficulties while exporting products to the United States, which makes Thai products that, are in their production chains more difficult to export as well. Other products, that are not in Chinese supply chain, such as agricultural food products, will benefit through exports replacing Chinese products at the US market and/or replacing the US products in China.

Companies in Thailand began to change their supply chain policies to prepare for the trade war, especially IT companies, textile companies, furniture and agricultural enterprises.

Consumption and investments will slow down, therefore, Thai government is taking economic support measures to prevent exports and the economy overall from slowing down which potentially may affect the employment chain, consumer spending and various business sectors.

\section{Conclusion}

All aspects and factors mentioned in the research as related to the trade war between China and the US may hinder trade not only between these two countries but also their trade with others. This means countries should think about having a wider option of whom to trade with or which country should they invest in. In the future, this may cause a disruption at 
various related markets and may even strengthen the competition between China and the USA further.

While this trade war is taking place between two global superpowers, Thailand could face both direct and indirect impacts. The most immediate direct effect which can arise very soon is that mutual tariff imposition may cause the products of both trade giants to be dumped into Thailand, thus resulting in stiffer competition with Thai domestic products. However, imposition of tariffs between the US and China may also lead to an increase in the demand for Thai products that are substitutable at these two huge markets.

\section{References:}

Arunmas, P. (2018). Commerce Ministry wants more SMEs to get in export game. Retrieved from: https://www.bangkokpost.com/business/news/1555806/commerce-ministry-wants-more-smesto-get-in-export-game

BBC News (2019). Trump declares national emergency over IT threats. Retrieved from: https://www.bbc.com/news/world-us-canada-48289550

Brown, C. P. \& Kolb, M. (2018). Trump's trade war timeline: An up-to-date guide. Retrieved from: https://piie.com/blogs/trade-investment-policy-watch/trump-trade-war-china-date-guide

Chaitrong, W. (2018). US-China trade war will hurt Thai exports: Experts. Retrieved from: http://www.nationmultimedia.com/detail/business/30341617

Dixon, L. (n.d.). Free trade. Retrieved from: https://www.britannica.com/topic/free-trade

Guarino, A.S. (2018). The Economic Effects of Trade Protectionism. Retrieved from: https://www.focus-economics.com/blog/effects-of-trade-protectionism-on-economy

IMF (2001). Global trade liberalization and the developing countries. Retrieved from: https://www.imf.org/external/np/exr/ib/2001/110801.htm

Kasikorn Research (2018). Trade War likely to be prolonged in 2019 ... possibly affecting Thai exports at 0.5\%-0.6\% of GDP (Issue No. 2922). Retrieved from: https://kasikornresearch.com/en/analysis/k-econ/economy/Pages/z2922.aspx

Kling, A. (n.d.). International trade. Retrieved from: https://www.econlib.org/library/Enc/InternationalTrade.html

Limviphuwat, P. (2019A). Thai export pay price for US-China trade war. Retrieved from: https://www.nationmultimedia.com/detail/business/30369844

Limviphuwat, P. (2019B). Thailand to push RCEP deal this year. Retrieved from: https://www.nationmultimedia.com/detail/Economy/30363107

MFA (2019). Press statement by the chairman of the ASEAN foreign ministers' retreat. Retrieved from: http://www.mfa.go.th/main/en/news3/6885/98574-Press-Statement-by-the-Chairman-ofthe-ASEAN-Forei.html

Money2know (2019). What is the country that distorts the currency in the US perspective?: Why Thailand survived? Retrieved from: https://money 2 know.com

NESDB (2019). NESDB advises on the export of Thai products under the trade war and the global economic slowdown. Retrieved from: https://www.nesdb.go.th

Office of the National Economic and Social Development Council. (2019). Gross domestic product: Q4/2018. Retrieved from: https://www.nesdb.go.th/nesdb_en/article_attach/article_file_20190218113428.pdf

Photirat, J. (2018). Thai Exports in September Dropped Unexpectedly by 5.2\% as US-China Trade War Escalated. Retrieved from: https://www.scbeic.com/en/detail/product/5112

Rapoza, K. (2019). Thailand sees threefold increase in Chinese companies looking to move. Retrieved from: https://www.forbes.com/sites/kenrapoza/2019/06/10/thailand-sees-threefoldincrease-in-chinese-companies-looking-to-move/\#1369ff62388f 


\section{THE US-CHINA TRADE WAR AND ITS IMPACT}

SCB EIC (2018). Potential impacts on Thailand from a US-China trade war. Retrieved from: https://www.bangkokpost.com/business/news/1464862/potential-impacts-on-thailand-from-aus-china-trade-war

Shaiken, H. (2015). The impact of international free-trade agreements on job growth and prosperity. Retrieved from: https://journalistsresource.org/studies/economics/business/international-freetrade-agreements-job-growth-prosperity-impacts/

Snyder, M. (2019). Stocks crater - 3.5 trillion dollars in global market cap wiped out - China considers "dumping U.S. treasuries". Retrieved from: http://theeconomiccollapseblog.com/archives/stocks-crater-3-5-trillion-dollars-in-globalmarket-cap-wiped-out-china-considers-dumping-u-s-treasuries

Sritama, S. (2019). Tourism council predicts $40.3 \mathrm{~m}$ arrivals for 2019. Retrieved from: https://www.bangkokpost.com/business/news/1596646/tourism-council-predicts-40-3marrivals-for-2019

Tan, H. (2019). China's current GDP growth is likely less than 6\%, economist says. Retrieved from: https://www.cnbc.com/2019/01/08/chinas-current-gdp-growth-is-likely-less-than-6-percenteconomist.html

Thaichareon, K. (2019). Thai Jan exports fall 5.7 percent year-on-year, a bigger drop than forecast. Retrieved from: https://forum.thaivisa.com/topic/1085755-thai-jan-exports-fall-57-percentyear-on-year-a-bigger-drop-than-forecast/

Thailand Business News (2016). Thailand 4.0, what do you need to know? Retrieved from: https://thaiembdc.org/thailand-4-0-2/

The Guardian (2019). China tells US provoking trade disputes is 'naked economic terrorism'. Retrieved from: https://www.theguardian.com/world/2019/may/30/china-tells-us-provokingtrade-disputes-is-naked-economic-terrorism

Trading Economics (2019). Thailand exports. Retrieved from: https://tradingeconomics.com/thailand/exports

Wong, D. \& Koty, A.C. (2019). The US-China trade war: A timeline. Retrieved from: https://www.china-briefing.com/news/the-us-china-trade-war-a-timeline/

Workman, D. (2019). Thailand's top 10 exports. Retrieved from: $\mathrm{http}: / / \mathrm{www}$.worldstopexports.com/thailands-top-10-exports/

York, E. (2018). The impact of trade and tariffs on the United States. Retrieved from: https://taxfoundation.org/impact-of-tariffs-free-trade /

Paper submitted

Paper accepted for publishing

Paper published online
11 December 2019

06 February 2020

02 April 2020 